Article Type: Research Paper

\title{
The Effect of Firm Size, Profitability, and Liquidity on The Firm Value Moderated by Carbon Emission Disclosure
}

\author{
Dody Hapsoro*1 and Zaki Naufal Falih ${ }^{2}$
}

\begin{abstract}
:
Research aims: The purpose of this study is to examine carbon emission disclosure in moderating the effect of firm size, profitability, and liquidity on the firm value.

Design/Methodology/Approach: The sample used in this study was firms engaged in the oil, gas, and coal fields and operating in non-Annex 1 member countries registered in the Osiris database. The study period was following the commencement of the Kyoto Protocol's second commitment from 2015 to 2018. Data analysis in this study used Partial Least Square (PLS) with Warp PLS 4.0 application.

Research findings: The study results showed that firm size and liquidity had a positive and significant effect on firm value. However, profitability had a positive and insignificant effect on firm value. Besides, carbon emission disclosure moderated the effect of firm size and profitability on firm value. However, carbon emission disclosure did not moderate the effect of liquidity on firm value. Theoretical contribution/ Originality: This study provides insight that carbon emission disclosure can moderate the effect of firm size and profitability variables on firm value.
\end{abstract}

AFFILIATION:

${ }^{1}$ STIE YKPN Yogyakarta, Daerah Istimewa Yogyakarta, Indonesia

${ }^{2}$ KAP Purwantono, Sungkoro \& Surja - Ernst \& Young, DKI Jakarta, Indonesia

\section{*CORRESPONDENCE: \\ dodyhapsoro@gmail.com}

THIS ARTICLE IS AVAILABLE IN:

http://journal.umy.ac.id/index.php/ai

DOI: 10.18196/jai.2102147

\section{CITATION:}

Hapsoro, D., \& Falih, Z. N. (2020)

The Effect of Firm Size,

Profitability, and Liquidity on The Firm Value Moderated by Carbon Emission Disclosure. Journal of Accounting and Investment, 21(2), 240-257.

Practitioner/Policy implication: This study is expected to encourage firms to be more concerned about the environment. Furthermore, the political contribution that can be provided by the results of this study is expected to motivate the government to apply more stringent regulations to firms that have the potential to generate carbon emissions.

Research limitation/Implication: Limitation in this study is the amount of data from oil firms, gas, and coal contained in the Osiris database in 2015 until 2018 was very limited.

\section{ARTICLE HISTORY}

\section{Received:}

24 Jan 2020

Keywords: Firm Size; Profitability; Liquidity; Carbon Emission Disclosure; Firm Value

Reviewed:

8 Apr 2020

Revised:

13 Apr 2020

Accepted:

21 Apr 2020

\section{Introduction}

Increased global warming and endless climate change make many government and non-government institutions jointly create interconnected rules to address the problems. Awareness-raising to reduce global warming should be done by the wider community and related parties (Rani, Hasan, \& Ilham, 2013). 
The Effect of Firm Size, Profitability, and Liquidity on The Firm Value Moderated ...

Environmental preservation that is not appropriately conducted will cause disasters, such as floods, landslides, heat waves, disease outbreaks, pollution of wells caused by untreated waste, wildfires, and others (Anggraeni, 2015). Such disasters can cause disruption of human activities and the firm's operational chains. When the firm's operational chain is disrupted, the economy of the firm and even the economy of the country can also be disrupted.

A system is needed to control the firm's negative impact on the environment. The system contains measurements, assessments, disclosures, and controls related to waste, pollution, or other factors that could harm the environment. The government is expected to play a role in helping to overcome these problems by issuing appropriate regulations related to social and environmental responsibility. Currently, the negative impacts caused by the firm's operational activities are not only perceived by the environment around the firm but also spread to other areas that are more widespread and detrimental to many parties (Pratiwi, 2017).

Sodiq and Kartikasari (2009) stated that economic activity became one of the triggers of global warming. Industry growth is positively correlated with the increase in emissions from the firm's operations (Anggraeni, 2015). Therefore, stakeholders expect the disclosure of information related to carbon emissions. It is also supported by the rules contained in the Kyoto Protocol, which regulate carbon emission disclosure. The beginning of the Kyoto Protocol came from the first world climate conference held on 12-23 February 1979 in Geneva (Switzerland). The conference was held to address issues triggered by human activities that impacted climate change. The next important milestone was the holding of the United Nations Framework Convention on Climate Change (UNFCCC) in 1992. The member states of the convention were asked to reduce emissions to be achieved in 2000 as well as participate in a global action plan to prevent increases in greenhouse gas emissions. However, in 1995, it began to emerge concerning that the agreement already reached may not work as expected. In response, in 1997, in Kyoto, a conference was held to discuss the issue. The outcome of the conference was later called the Kyoto Protocol.

The Kyoto Protocol, according to a press release from the UN Environment Program, is a legal agreement that industrialized countries would reduce greenhouse gas emissions collectively by $5.2 \%$ compared to 1990 . The goal of reducing greenhouse gas emissions is to reduce the average emissions of the six greenhouse gases, including carbon dioxide, methane, nitrous oxide, sulfur hexafluoride, hydrofluorocarbon (HFC), and perfluorocarbon ( $\mathrm{PFC}$ ), which were calculated as an average over five years between 2008-2012.

The field of accounting as one of the social sciences has naturally contributed to the improvement of the negative things above. Therefore, it is necessary to report social and environmental responsibility that is disclosed to stakeholders, especially the general public, as a party that is much affected by the negative impact of the firm's operations. Recording and reporting on social and environmental accountability reports in annual financial reports published by the firm are expected to be useful for investors who are 
the buffer of life for the firm in the future. Thus, the importance of disclosure of carbon emission in the firm's financial statements can be the basis or reason for investors to invest their funds in the firm. Although in most countries of the world (including Indonesia), disclosure of carbon emission is still voluntary, firms willing to disclose carbon emission have added value in the eyes of both foreign and local investors (Prafitri \& Zulaikha, 2016). It also shows that firms that are willing to disclose carbon emissions are considered serious in terms of environmental conservation and, at the same time, think of the impacts caused by the firm's operational activities that are mostly in contact with the environment.

Based on the above description, carbon emission disclosure becomes an interesting issue to be investigated because the firm's operational activities cannot be separated from environmental issues. It is primarily for firms that have a major impact on the environment, such as the oil, gas, and coal industry (IPCC, 2014). Therefore, carbon emission disclosure is expected to be a positive signal about the firm's commitment to responding to environmental issues, and it is anticipated to get a positive investor response. With the size of the firm, profitability and liquidity followed by the carbon emission disclosure are expected to increase the positive effect on the firm value. It is corresponding to the results of Saka and Oshika's research (2014), which stated that the carbon emissions disclosure was positively related to the market value of equity and that the positive relationship became stronger in line with the amount or volume of carbon emissions that was getting bigger. Consequently, it is essential to consider the inclusion of carbon emissions disclosure as a component in the disclosure of nonfinancial aspects. It is also supported by the results of Hermawan, Aisyah, Gunardi, and Putri's (2018) study, which stated that firm size and profitability affected the disclosure of carbon emissions. However, research conducted by Matsumura, Prakash, and VeraMunoz (2014) found the opposite result, namely that on average, companies that disclosed carbon emissions of one thousand metric tons experienced a decline in corporate value of US $\$ 212,000$. Hence, research to test the ability of carbon emission disclosure in moderating the effect of firm size, profitability, and liquidity on the firm value becomes very important and needs to be carried out. The contributions of the current study, both theoretical and practical, are presented in the conclusion part.

\section{Literature Review and Hypotheses Development}

\section{Signaling Theory}

In the signaling theory proposed by Ross (1977), it is stated that a good financial statement is a signal that the firm has been operating properly. Signaling theory explains the causes of firms providing financial statement information to external parties.

Signal theory is the basis for companies to be willing to make voluntary disclosures, as stated in the company's annual report. The signal is in the form of information about the efforts made by management to realize investor desires. Signals can be in the form of certain information, for example, carbon information disclosure. The disclosure is a 
The Effect of Firm Size, Profitability, and Liquidity on The Firm Value Moderated ...

positive signal given by the company to investors, as well as providing information that the company has a concern for the environment. It is done by the company to attract investors to invest, increase the positive reputation, and at the same time, increase the value of the company.

\section{Agency Theory}

According to Jensen and Meckling (1976), agency theory explains the relationship of cooperation between principal and agent. In agency theory, it mentioned the separation of ownership and management of the firm. The separation will always be followed by the emergence of costs as a result of the absence of violence between the interests of the owner and the manager. The cost is called the agency cost. The assumption that the agency theory has is that each individual is motivated by his or her interests, thus creating a conflict of interest between the principal and the agent. Shaw (2003) considers that firm management as an agent of the shareholders will act with full awareness of his interests.

Principals and agents have interrelated positions. Capital owners or shareholders or principals have the right to get information from an internal company or agent. Agents have more complete and accurate information about the company's operational activities compared to the principal because the agent has a direct duty to carry out the company's operational activities. Therefore, information about carbon emissions revealed by management as an agent should also be known by the capital owner as of the principal, so it is hoped that the principal can make the right and accurate decisions according to his interests.

\section{Carbon Emission Disclosure}

Global warming is one of the major environmental issues faced by the world today. Global warming can cause changes in ecosystems in the earth, including melting ice that can cause sea-level rise and climate change in the extreme. Changes in these ecosystems can adversely affect the survival of humans and living things on earth.

With the increasing operation of firms that produce carbon gas, then it can be one cause of the increase in world carbon emissions. The firm is expected to make transparency to the public, especially investors, that the firm has shown concern for the environment. Firms can realize such transparency by disclosing carbon emissions information. Through the disclosure, it is expected that the public, especially investors, will increasingly believe that not only financial reports that need to be considered but also other important information such as carbon emission disclosure.

\section{Firm Size}

Resources owned by the firm can be reflected in its size. The larger the size of the firm, the higher its resources (Choi, Lee, \& Psaros, 2013). The size of the firm is measured by the size of the firm's assets. The size of the firm is one factor that investors consider for 
The Effect of Firm Size, Profitability, and Liquidity on The Firm Value Moderated ...

investing. Large firms tend to provide detailed information to meet the information needs of their users, such as investors, management, government, and other information users.

\section{Profitability}

Profitability is the main attraction for the shareholder because it is the result obtained through the management effort on the funds invested by the shareholders, and it reflects the profits that are the rights of shareholders (Jusriani \& Rahardjo, 2013). Profitability is considered vital because it is an indicator to measure the financial performance of a firm, so it can be employed as a reference to assess the firm (AlMatari, Al-Swidi, \& Hanim, 2014).

\section{Liquidity}

According to Kasmir (2010), liquidity is a ratio that describes a firm's ability to meet short-term (debt) obligations. Meanwhile, according to Thaib and Dewantoro (2017), liquidity is defined as the ability of the firm to meet obligations or debts that must be paid with the current leverage. The liquidity ratio is used to measure the firm's ability to meet its short-term liabilities (Horne \& Wachowicz, 2001). This ratio can be calculated through sources of information about working capital, i.e., current asset items, or liquid assets (Brigham \& Houston, 2010).

\section{Firm Value}

The primary purpose of a firm that has gone public is to increase the prosperity of the owner or shareholders by increasing the firm value (Salvatore, 2005). Firm value is very important because of the high value of the firm will be followed by high shareholder wealth (Brigham \& Houston, 2010). The firm value is crucial to know because it reflects the firm's performance and can affect the perception of investors on the firm.

This study was conducted to answer the research gap due to differences in the results of previous studies that have not found consistent results in seeing the presence of carbon emission disclosure. In this study, the carbon emission disclosure variable was placed as a variable that was thought to be able to moderate the effect of firm size, profitability, and liquidity on the firm value. The existence of carbon emission disclosure is an interesting issue to study because the company's operational activities cannot be separated from environmental issues. The results of Saka and Oshika's research (2014) stated that the carbon emissions disclosure was positively related to the market value of equity and that the positive relationship became stronger in line with the amount or volume of carbon emissions that was getting bigger. Therefore, it is crucial to consider the inclusion of carbon emissions disclosure as a component in the disclosure of nonfinancial aspects. It is supported by the results of Hermawan et al. (2018) research, which stated that company size and profitability affected the disclosure of carbon emissions. However, in the research of Matsumura et al. (2014), the opposite results were found, namely that on average, companies that disclosed carbon emissions of one 
The Effect of Firm Size, Profitability, and Liquidity on The Firm Value Moderated ...

thousand metric tons experienced a decrease in corporate value of US $\$ 212,000$. Therefore, the purpose of this study is to test the ability of carbon emission disclosure in moderating the effect of firm size, profitability, and liquidity on the value of firms located in the ASEAN region included in the Non-Annex I member of the Kyoto Protocol.

\section{The Effect of Firm Size on Firm Value}

Firm size describes the number of assets owned by the firm. These assets may be financial assets and non-financial assets (Irwantoko \& Basuki, 2016). Information on firm size is crucial to investors (Lischewski \& Voronkova, 2010). Large firms have several strategies to deal with risk. Therefore, large firms can process resources better than small firms (Chen \& Chen, 2011).

Research on the effect of firm size on firm value has been done by several researchers. Prasetia, Tommy, and Taerang (2014) stated that firm size affected firm value. Similar results were also revealed by Putra and Lestari (2016). However, the results of Hermawan and Mafulah's (2014) study showed that firm size did not influence firm value. Based on the above description, the researchers proposed the following hypothesis:

$H_{1}$ : Firm size has a significant role in increasing firm value

\section{The Effect of Profitability on Firm Value}

Profitability is the firm's ability to generate profits over some time. Every firm wants a high level of profitability. The firm must have the advantage of being able to live its life. If the firm is in an unfavorable condition, it will be difficult for the firm to obtain loans from external creditors or investments. The higher the profitability ratio reflects a higher level of profit earned by the firm (Fahmi, 2011). Firms with high profitability are considered to have good performance.

Research on the effect of profitability on firm value has been conducted by several researchers. Chen and Chen (2011) and Anjarwati, Chabachib, Demi (2016) revealed that profitability had a positive and significant impact on firm value. However, the results of Thaib and Dewantoro (2017) studies showed that profitability did not affect firm value. Based on the above description, the researchers proposed the following hypothesis:

$\mathrm{H}_{2}$ : Profitability has a significant role in increasing firm value

\section{The Effect of Liquidity on Firm Value}

The high level of liquidity of a firm describes the availability of firm funds to perform the firm's operational activities. Investors assume that firms with high liquidity levels have good prospects. The more liquid the firm indicates that the firm has a chance to 
The Effect of Firm Size, Profitability, and Liquidity on The Firm Value Moderated ...

continue growing. According to Thaib and Dewantoro (2017), the more liquid the firm, the higher the trust rate of creditors to lend the funds to increase the firm value in the eyes of creditors and potential investors.

Several researchers have carried out a study on the effect of liquidity on firm value. The result of Rompas's (2013) study showed that liquidity had a positive effect on firm value. Similar results were also revealed by Putra and Lestari (2016). However, in Hermawan and Mafulah (2014) research, liquidity did not affect firm value. Based on the above description, the researchers proposed the following hypothesis:

$\mathrm{H}_{3}$ : Liquidity has a significant role in increasing firm value

\section{The Effect of Firm Size on Firm Value with Carbon Emission Disclosure as Moderation Variable}

Investors need other considerations when they are going to invest. Big or small firms are not the sole determining factor when investors invest. Other information that investors need to consider when investing in the firm includes information on carbon emission disclosure. The larger the firm, the more pressure the environment provides to express matters relating to environmental issues and social responsibility (Choi et al., 2013). With the disclosure of information about carbon emissions, investors increasingly believe that the firm is the right place to invest. Brammer and Pavelin (2006) show that many large corporations are making voluntary disclosures to gain legitimacy.

Disclosure of carbon emissions information can be a positive signal for investors, and with this, the firm hopes that investors are willing to invest. The willingness of investors to invest their capital in the firm can increase the firm value. Based on the above description, the researchers proposed the following hypothesis:

$\mathrm{H}_{4}$ : Carbon emission disclosure moderates the effect of firm size on firm value

\section{The Effect of Profitability on Firm Value with Carbon Emission Disclosure as Moderation Variable}

Before investing, investors must observe financial statements. In the financial statements, the profitability of the firm is an interesting thing to observe. According to Jannah and Muid (2014), the higher profitability of the firm indicates that the financial performance of a firm is getting better. The better financial performance of a firm suggests that firms are financially capable of incorporating carbon emission reduction strategies into their business strategy. According to Freedman and Jaggi (2005), firms with good operating performance will make more detailed disclosure of the environment because they can produce more environmental impact reduction than other firms. 
The Effect of Firm Size, Profitability, and Liquidity on The Firm Value Moderated ...

According to Choi et al. (2013), firms with good financial conditions can afford to pay the human or financial supplemental resources required for voluntary reporting and carbon emission disclosure. Carbon emission disclosure is expected to encourage investors to be more confident to the firm by investing in the firm so that the firm value will increase. Based on the above description, the researchers proposed the following hypothesis:

$H_{5}$ : Carbon emission disclosure moderates the effect of profitability on firm value

\section{The Effect of Liquidity on Firm Value with Carbon Emission Disclosure as Moderation Variable}

The liquidity ratio is utilized to measure the firm's ability to meet its short-term liabilities (Horne \& Wachowicz, 2001). Liquidity management should be able to contribute to the realization of firm value creation (Michalski, 2010). Firms that have high liquidity levels are considered to have good prospects by investors (Putra \& Lestari, 2016). However, it should be supported by non-financial information for investors to have more confidence that the firm is the right firm to invest. Other non-financial information may be carbon emission disclosure. In general, the firm will disclose the information if the information will be able to increase the firm value. Conversely, if such information could harm the firm's position or reputation, then the firm will withhold such information (Jannah \& Muid, 2014).

Firm performance can affect the speed of the firm's response to pressure generated from the community. The response can be demonstrated through the disclosure of the environment, so that the higher the firm's performance, the faster the firm can cope with the pressures that arise by disclosing the environment faster (Jannah \& Muid, 2014). The firm cares and discloses information related to the environment because it wants to improve the firm's image as an investment destination (Irwantoko \& Basuki, 2016). Based on the above description, the researchers proposed the following hypothesis:

$H_{6}$ : Carbon emission disclosure moderates the effect of liquidity on firm value

The study of carbon emission disclosure conducted so far has generally placed it as an independent or dependent variable. The placement of carbon emission disclosure as an independent variable is intended to test the ability of that variable as the cause (antecedents), while the placement of carbon emission disclosure as the dependent variable is intended to test the ability of that variable as a result (consequences). Some examples of studies that place it on both variables include the Saka and Oshika's (2014) study entitled "Disclosure Effects, Carbon Emissions, and Corporate Value"; Matsumura et al. (2014) study entitled "Firm-Value Effects of Carbon Emissions and Carbon Disclosures"; Hermawan et al. (2018) study entitled "Going Green: Determinants of Carbon Emission Disclosure in Manufacturing Companies in Indonesia"; the study of 
The Effect of Firm Size, Profitability, and Liquidity on The Firm Value Moderated ...

Hapsoro and Ambarwati (2018) entitled "Antecedents and Consequences of Carbon Emissions' Disclosure: Case Studies of Oil, Gas and Coal Companies in Non-Annex 1 Member Countries". Whereas in this current study, researchers placed carbon emission disclosure as a moderating variable. The purpose of the placement is to increase the role of the carbon emission disclosure variable in which its existence and role are fundamental in moderating the effect of firm size, profitability, and liquidity on the firm value.

The research model of the current study is shown in Figure 1.

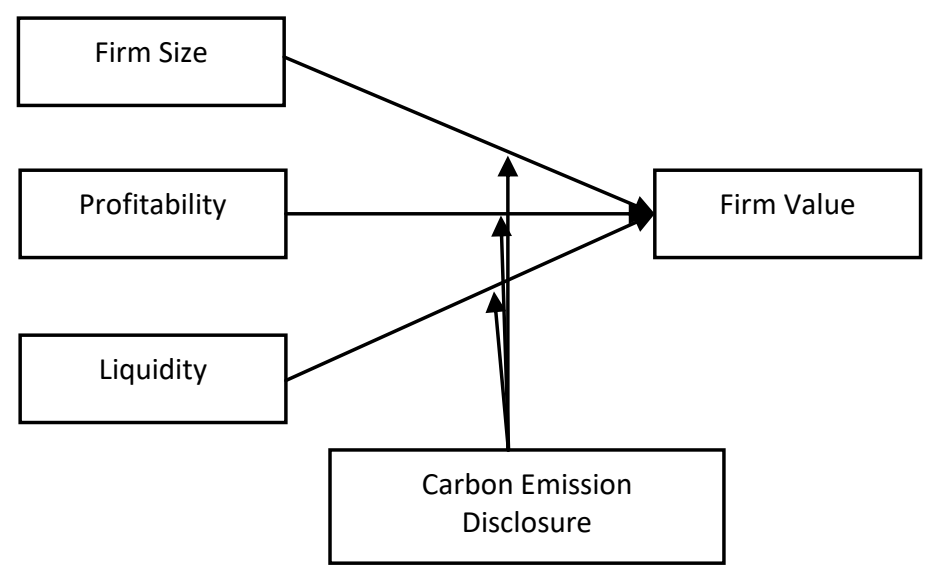

Figure 1 Research Model

\section{Research Method}

\section{Population and Sample}

The population observed in this research was oil, gas, and coal firms in the ASEAN region contained in the Osiris database 2015-2018. The year was chosen because it was the year of implementation of the Kyoto Protocol's second commitment. Oil, gas, and coal firms were selected because they are the industries that contribute to the most carbon emissions in the world. The sampling technique used was purposive sampling with criteria of firms that have completed the annual report in the year of 2015-2018 in English or Indonesia. The number of firms that met the criteria was 65 firms.

\section{Operational Measurement of Variables}

\section{Carbon Emission Disclosure}

This variable was measured by giving a score of 1 on firms that disclosed carbon emissions and a score of 0 for those who did not do so. The items to measure carbon emission disclosure were adopted from the research of Choi et al. (2013). 
The Effect of Firm Size, Profitability, and Liquidity on The Firm Value Moderated ...

Firm Size

According to Choi et al. (2013, the size of the firm is a reflection of the size of the firm that appears in the total firm value's assets on the balance sheet. Therefore, in this study, the size of the asset was calculated as the logarithm of the total assets, as follows:

$$
\text { Size }=\operatorname{Ln} \text { Total Assets }
$$

Profitability

According to Sartono (1998), profitability is a firm's ability to earn profits concerning sales, total assets, and own capital. ROA was calculated by the following formula:

Liquidity

$$
\text { ROA }=\frac{\text { Laba Setelah Pajak }}{\text { Total Aset }}
$$

In this research, liquidity was proxied with the current ratio (CR). The current ratio (CR) is the ratio used to measure a firm's ability to repay short-term debt employing current assets (Thaib \& Dewantoro, 2017). CR was measured by the following formula:

$$
\mathrm{CR}=\frac{\text { Current Asset }}{\text { Current Liabilities }}
$$

Firm Value

In this research, the firm value was proxied using Tobin's $Q$ or $Q$ ratio. Tobin's $Q$ formula proposed by Chung and Pruitt (1994) is as follows:

$$
\text { Tobin's Q }=\frac{(\text { MVCS }+ \text { PS }+ \text { BVD })}{\text { Total Asset }}
$$

Description:

MVCS = Market value of common stock

PS = Preferred stock

BVD = Book value of debt

\section{Data Analysis Method}

The method of analysis used in this research was the structural equation modeling (SEM) method, and the analysis tool employed was partial least square software (PLS). SEM is one type of multivariate analysis in social science. The software utilized as an analytics tool was WarpPLS version 4.0. 
The Effect of Firm Size, Profitability, and Liquidity on The Firm Value Moderated ...

\section{Result and Discussion}

\section{Description of Research Objects}

This research used the samples of oil, gas, and coal firms in non-Annex 1 member countries contained in the Osiris database. Based on the data obtained, it was known that all data of oil, gas, and coal firms in non-Annex 1 member countries in the Osiris database in 2015 - 2018 were 88 firm data. Of these, only 65 firm data met the sample criteria.

\section{Partial Least Square Analysis}

Partial least square (PLS) analysis was used to measure the goodness of fit model, calculated by looking at the average R-squared (ARS) to show the suitability of the model, the average path coefficient (APC) to reveal the interrelations between variables, and the average variance inflation factor (AVIF) to indicate the multicollinearity among independent variables.

Table 1 The Goodness of Fit Model

\begin{tabular}{cccc}
\hline Result & $\mathrm{P}$-Value & Criteria & Description \\
\hline APC $=0,219$ & $\mathrm{P}=0,004$ & Good if $\mathrm{P}<0,05$ & Supported \\
ARS $=0,468$ & $\mathrm{P}<0,001$ & Good if $\mathrm{P}<0,05$ & Supported \\
AVIF $=1,292$ & & $\mathrm{P}<5$ & Supported \\
\hline
\end{tabular}

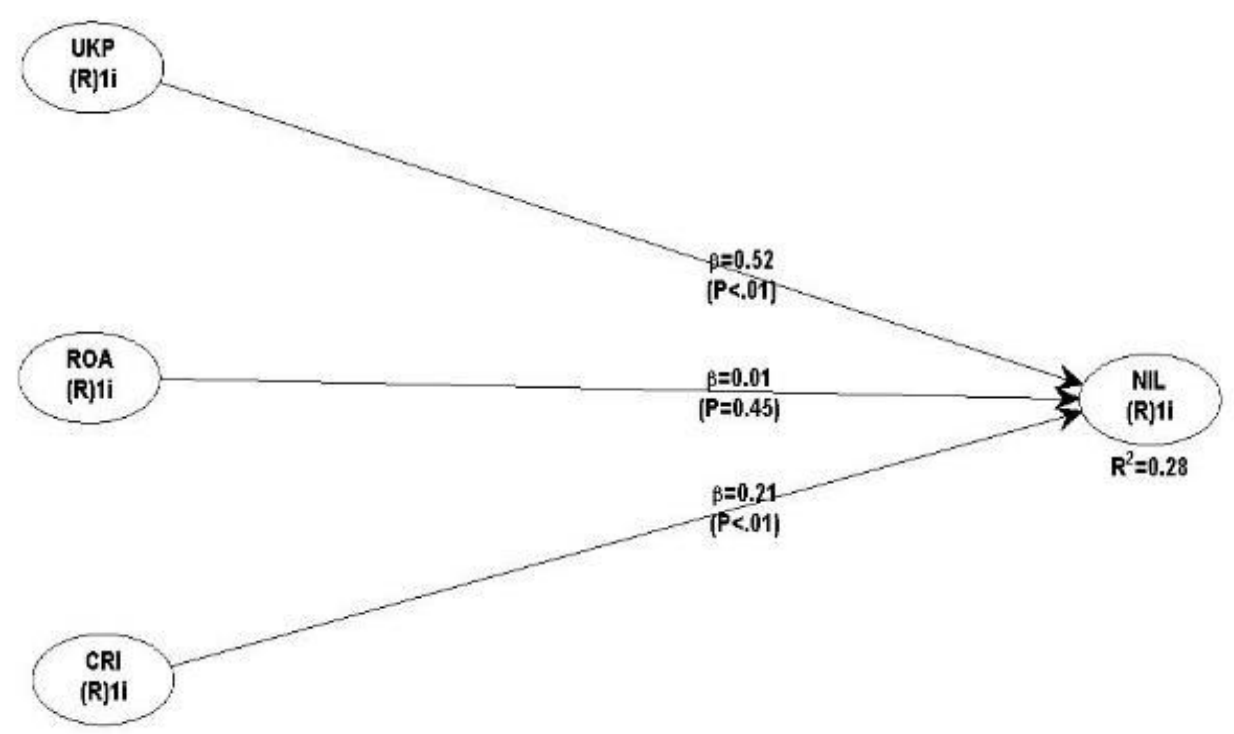

Figure 2 Hypothesis Testing Results Before Using Moderation Variables 


\section{Hapsoro \& Falih}

The Effect of Firm Size, Profitability, and Liquidity on The Firm Value Moderated ...

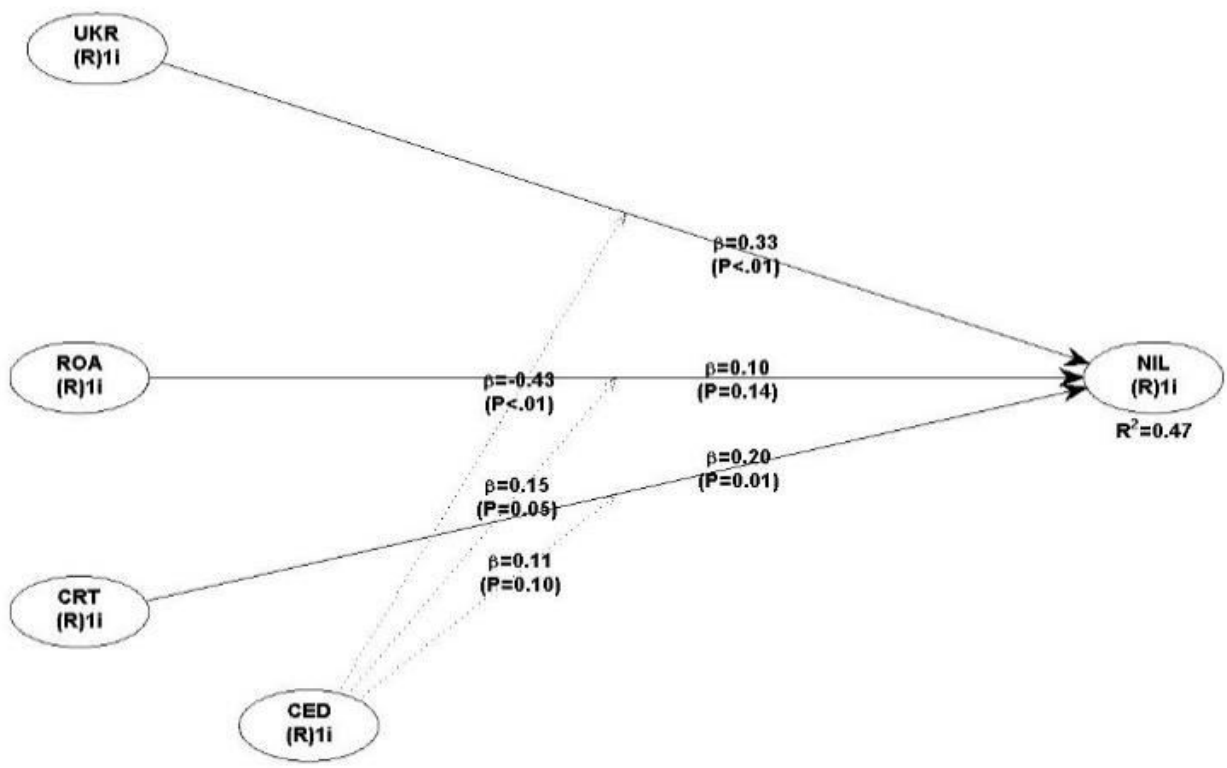

Figure 3 Hypothesis Testing Results After Using Moderation Variables

Table 2 Descriptive Statistics

\begin{tabular}{cccccc}
\hline & N & Minimum & Maximum & Mean & Std. Deviation \\
\hline UKP & 65 & 16,40 & 29,11 & 22,0936 & 3,31728 \\
ROA & 65 & $-1,61$ & 1,75 & 0,0262 & 0,31970 \\
CRI & 65 & 0,01 & 6,90 & 1,9152 & 1,41962 \\
CED & 65 & 1 & 17,00 & 8,2154 & 4,56376 \\
NIL & 65 & 0,02 & 3,76 & 0,7880 & 0,70364 \\
\hline
\end{tabular}

\section{Hypothesis Testing Results}

Firm size has a significant role in increasing firm value

Based on the results of the first hypothesis testing in this study, it could be seen that $p$ value $(<0.01$ ) was smaller than the specified significance level ( $\leqslant 0.05)$, and the value of the path coefficient was positive (0.33). It showed that firm size proved to have a positive and significant impact on firm value, so the test result supported the first hypothesis. The larger the firm's size, the higher the firm's value. It is because the larger the size of the firm, the higher the assets, market share, and resources owned by the firm, so the size of the firm is one thing to consider by investors before investing capital. The results of the first hypothesis testing support the research of Putra and Lestari (2016), which stated that the size of the firm positively affected the firm value. 
The Effect of Firm Size, Profitability, and Liquidity on The Firm Value Moderated ...

Profitability has a significant role in increasing firm value

Based on the results of the second hypothesis testing in this study, it could be seen that $p$-value $(0.14)$ was higher than the specified significance level $(\leqslant 0.05)$, and the value of the path coefficient was positive (0.10). It indicated that profitability had no effect on firm value, so the test result did not support the second hypothesis. Profitability did not affect firm value because, in the year 2015-2018, oil, gas, and coal industries were experiencing a sales decline, which resulted in decreased profits and declining investment decisions of investors in this industry. It is consistent with the statement made by Camoin Associates on December 9, 2019, and published in a report entitled "Economic Trends in the Oil, Gas and Coal Industries" (Meys \& Damicis, 2019). The report stated that between 2008 and 2018, there was a decline in sales in the oil, gas, and coal industry, which subsequently resulted in a decrease in the number of workers ranging from 6.7 percent to 37.0 percent, or overall, a decline in the number of workers by 20 percent of all industry.

Liquidity has a significant role in increasing firm value

Based on the result of the third hypothesis testing in this study, it could be seen that $p$ value $(0,01)$ was smaller than the specified significance level $(\leqslant 0,05)$, and the value of the path coefficient was positive $(0,20)$. It signified that liquidity proved to have a positive effect on firm value, so the test results supported the third hypothesis. High liquidity indicates that firm funds are available to finance the firm's operations and investments so that the investors' perceptions of firm performance is getting better (Putra \& Lestari, 2016). The higher the liquidity, the higher the firm value. The third hypothesis test results support Firnanda and Oetomo's research (2016), which stated that liquidity had a positive effect on firm value.

\section{Carbon Emission Disclosure Moderates the Effect of Firm Size on Firm Value}

Based on the results of the fourth hypothesis testing in this study, it could be seen that $p$-value $(<0.01)$ was smaller than the specified significance level $(\leqslant 0.05)$, and the value of the path coefficient was negative $(-0.43)$. It implied that carbon emission disclosure weakened the effect of firm size on firm value. Not all companies disclose carbon emissions, and large companies do not always pay attention to the importance of disclosing carbon emissions information so that the information required by investors is not met.

\section{Carbon Emission Disclosure Moderates the Effect of Profitability on Firm Value}

Based on the result of the fifth hypothesis testing in this study, it could be seen that $p$ value $(0,05)$ was equal to the specified significance level $(\leqslant 0,05)$, and the value of the path coefficient was positive $(0,15)$. It means that carbon emission disclosure could strengthen the effect of profitability on the firm value. Increasing profitability and the increasing amount of information revealed in the carbon emission disclosure can increase firm value. It shows that investors not only pay attention to the profit but also 
The Effect of Firm Size, Profitability, and Liquidity on The Firm Value Moderated ...

pay attention to the firm's responsibility to the environment as a form of mutual relation of the firm to the environment. Reciprocal relationship in the form of environment provides production resources for firms, and the firms maintain and take care of the environment for the firm's operational activities to continue.

\section{Carbon Emission Disclosure Moderates the Effect of Liquidity on Firm Value}

Based on the results of the sixth hypothesis testing in this study, it could be seen that $p$ value $(0.10)$ was higher than the specified significance level $(\leqslant 0.05)$, and the value of the path coefficient was positive (0.11). It indicated that carbon emission disclosure did not moderate the effect of liquidity on firm value. These results suggest that investors will see more the firm's ability to finance the firm's operations and investments than social and environmental disclosures in the form of carbon emission disclosure. It is because investors only see in terms of financial performance that can contribute to the firm value, so the disclosure of social information in the annual report does not affect investors in investing.

\section{Conclusion}

Based on the results of the previous discussion, several conclusions could be determined, as follows: firm size had a significant role in increasing firm value, profitability did not have a significant role in increasing firm value, liquidity had a significant role in increasing firm value, carbon emission disclosure could moderate the effect of firm size on the firm value, and carbon emission disclosure could moderate the effect of profitability on the firm value.

This study successfully demonstrated and proved the importance of carbon emission disclosure as a moderating variable because the variable could moderate the effect of firm size on the firm value and had the ability to moderate the effect of profitability on the firm value. Research conducted so far has generally placed carbon emission disclosure as an independent variable or dependent variable. However, in this study, the carbon emission disclosure variable was placed as a moderating variable, and the results of the study succeeded in proving that the carbon emission disclosure variable was able to be a variable that could moderate other variables. Therefore, this study provides a new perspective on the importance of the carbon emission disclosure variable in subsequent studies.

The results of this study provide several contributions. The theoretical contribution that can be given by the results of this study is that carbon emission disclosure can moderate the effect of firm size and profitability variables on firm value. While the practical contribution that can be offered by the results of this study is expected to encourage companies to be more concerned about the environment, especially the environment affected by carbon emissions so that companies receive a positive response from investors. It is because investors are more interested in companies that disclose carbon emissions compared to companies that do not disclose carbon emissions. Furthermore, 
The Effect of Firm Size, Profitability, and Liquidity on The Firm Value Moderated ...

the political contribution that can be provided by the results of this study is that it is expected to motivate the government to apply more stringent regulations to firms that have the potential to generate carbon emissions. The regulation, for example, involves the implementation of mandatory disclosure against firms that have the potential to generate carbon emissions. If the regulation is implemented, firms are more concerned about the environment and global warming and are expected to reduce the volume of carbon emissions in the earth's atmosphere. It is supported by the results of research showing that carbon emission disclosure strengthens the effect of profitability on firm value, and similarly, carbon emission disclosure also strengthens the effect of firm size on firm value.

The limitation of this study is that the amount of data from oil firms, gas, and coal contained in the Osiris database in 2015 until 2018 was very limited. It is due to the language differences, incomplete annual reports, and the lack of information disclosed in the annual report. Based on the existing limitations, further research is suggested to add the number of samples by using other databases that provide firm annual reports across the country. Further research can also add other independent variables, such as earnings per share and corporate governance.

\section{References}

Al-Matari, E. M., Al-Swidi, A. K., \& Fadzil, F. H. Bt.. (2014). The Measurements of Firm Performance's Dimensions. Asian Journal of Finance \& Accounting, 6(1), 24-49. https://doi.org/10.5296/ajfa.v6i1.4761

Anggraeni, D. Y. (2015). Pengungkapan Emisi Gas Rumah Kaca, Kinerja Lingkungan, Dan Nilai Perusahaan. Jurnal Akuntansi dan Keuangan Indonesia, 12(1), 1-18. http://dx.doi.org/10.21002/jaki.2015.11

Anjarwati, K., Chabachib, M. \& Pengestuti, I. D. (2016). Pengaruh Profitabilitas, Size, dan Likuiditas Terhadap Nilai Perusahaan Manufaktur di Indonesia Dengan Struktur Modal Sebagai Variabel Intervening. Studi Empiris Pada Perusahaan Manufaktur yang Terdaftar di Bursa Efek Indonesia Tahun 2012-2015. Thesis Masters. Diponegoro University Management, Semarang. Retrieved from http://eprints.undip.ac.id/51133/

Brammer, S. \& Pavelin, S. (2006). Voluntary Environmental Disclosures by Large UK Firms. Journal of Business Finance \& Accounting, 33(7-8), 1168-1188. https://doi.org/10.1111/j.1468-5957.2006.00598.x

Brigham, E. F., \& Houston, J. F. (2010). Fundamentals of Financial Management Book 1 (Vol. II). Jakarta: Salemba Empat.

Chen, L. J. \& Chen, S. Y. (2011). The Influence of Profitability on Firm Value With Capital Structure as The Mediator and Firm Size and Industry as Moderators. Investment Management and Financial Innovations, 8(3), 121-129. Retrieved from https://businessperspectives.org/images/pdf/applications/publishing/templates/arti cle/assets/4210/imfi_en_2011 03 Chen.pdf

Choi, B. B., Lee, D. \& Psaros, J. (2013). An analysis of Australian Firm Carbon Emission Disclosures. Pacific Accounting Review, 25(1), 58-79. https://doi.org/10.1108/01140581311318968

Chung, K. H., \& Pruitt, S. W. (1994). A Simple Approximation of Tobin's Q. Financial Management Journal, 23(3), 70-74. https://doi.org/10.2307/3665623 


\section{Hapsoro \& Falih}

The Effect of Firm Size, Profitability, and Liquidity on The Firm Value Moderated ...

Fahmi, I. (2011). Analysis of Financial Statements. Bandung: Alfabeta.

Firnanda, T., \& Oetomo, H. W. (2016). Analisis Likuiditas, Profitabilitas, Solvabilitas, dan Perputaran Persediaan Terhadap Nilai Perusahaan. Jurnal Ilmu Dan Riset Manajemen, 5(2), 1-15. Retrieved from

https://scholar.google.com/scholar?hl=en\&as_sdt=0,5\&cluster $=1669364484221762$ $\underline{0517}$

Freedman, M. \& Jaggi, B. (2005). Global Warming, Commitment to The Kyoto Protocol, and Accounting Disclosures by The Largest Global Public Firms From Polluting Industries. The International Journal of Accounting, 40(3), 215-232. Retrieved from https://www.researchgate.net/publication/223558782_Global_Warming_Commitme nt to the Kyoto Protocol and Accounting Disclosures by the Largest Global P ublic Firms from Polluting Industries

Hapsoro, D., \& Ambarwati. (2018). Antecedents and Consequences of Carbon Emissions' Disclosure: Case Studies of Oil, Gas and Coal Companies in Non-Annex 1 Member Countries. Journal of Indonesian Economy and Business, 33(2), 299-111. https://doi.org/10.22146/jieb.28756

Hermawan, A, Aisyah, I. S., Gunardi, A., \& Putri, W. Y. (2018). Going Green: Determinants of Carbon Emission Disclosure in Manufacturing Companies in Indonesia. International Journal of Energy Economics and Policy, 8(1), 55-61. Retrieved from https://www.econjournals.com/index.php/ijeep/article/view/6009

Hermawan, S \& Mafulah, A. N. (2014). Pengaruh Kinerja Keuangan terhadap Nilai Perusahaan dengan Pengungkapan Corporate Social Responsibility sebagai Variabel Pemoderasi. Jurnal Dinamika Akuntansi, 6(2), 103-118. https://doi.org/10.15294/jda.v6i2.3250

Horne, J. C. V. \& Wachowicz, J. M. J. (2001). Fundamentals of Financial Management. New Jersey: Pearson Prentice Hall.

Irwantoko \& Basuki. (2016). Carbon Emission Disclosure: Studi pada Perusahaan Manufaktur Indonesia. Jurnal Akuntansi dan Keuangan, 18(2), 92-104. https://doi.org/10.9744/jak.18.2.92-104

Ja'far, S. M., \& Kartikasari, L. (2009). Carbonaccounting: Implikasi Strategis Perekayasaan Akuntansi Manajemen. Simposium Nasional Akuntansi 12 Palembang.

Jannah, R., \& Muid, D. (2014). Analisis Faktor-Faktor yang Mempengaruhi Carbon Emission Disclosure Pada Perusahaan di Indonesia (Studi Empiris pada Perusahaan yang Terdaftar di Bursa Efek Indonesia Periode 2010-2012). Diponegoro Journal of Accounting, 3(2), 2337-3806. Retrieved from https://media.neliti.com/media/publications/251407-analisis-faktor-faktor-yangmempengaruhi-76f43a1f.pdf

Jensen, M. C. \& Meckling, W. H. (1976). The Theory of The Firm: Managerial Behavior, Agency Cost, and Ownership Structure. Journal of Financial Economics, 3(4), 305-360. https://doi.org/10.1016/0304-405X(76)90026-X

Jusriani, F. I. \& Rahardjo, N. S. (2013). Analisis Pengaruh Profitabilitas, Kebijakan Dividen, Kebijakan Utang, dan Kepemilikan Manajerial Terhadap Nilai Perusahaan. Diponegoro Journal of Accounting, 2(2), 1-10. Retrieved from https://media.neliti.com/media/publications/242806-analisis-pengaruh-profitabilitaskebijak-351e31a3.pdf

Kasmir. (2010). Analisis Laporan Kenangan. Jakarta; PT. Rajawali.

Lischewski, J. \& Voronkova, S. (2010). Size, Value, and Liquidity: Do They Really Matter on an Emerging Stock Market?. ZEW Discussion Papers, 10-070. https://www.econstor.eu/bitstream/10419/41434/1/636381676.pdf 
The Effect of Firm Size, Profitability, and Liquidity on The Firm Value Moderated ...

Matsumura, E. M., Prakash, R., \& Vera-Munoz, S. C. (2014). Firm-Value Effects of Carbon Emissions and Carbon Disclosures. The Accounting Review, 89(2), 695-724. https://dx.doi.org/10.2139/ssrn.1921809

Meys, B., \& Jim Damicis. (2019). Economic Trends in the Oil, Gas and Coal Industries. Saratoga Springs, NY: eNewsletter.

Michalski, G. (2010). Planning Optimal from the Firm Value Creation Perspective: Levels of Operating Cash Investments. Romanian Journal of Economic Forecasting, 13(1), 198-214. Retrieved from https://www.researchgate.net/publication/227489743_Planning_Optimal_From The Firm Value Creation Perspective_Levels_Of_Operating_Cash_Investments

Prafitri, A. \& Zulaikha. (2016). Analisis Pengungkapan Emisi Gas Rumah Kaca. Jurnal Akuntansi \& Auditing, 13(2), 155-175. Retrieved from https://media.neliti.com/media/publications/73347-ID-analisis-pengungkapan-emisigas-rumah-ka.pdf

Prasetia, T. E., Tommy, P. \& Saerang, I. S. (2014). Struktur Modal, Ukuran Perusahaan dan Risiko Perusahaan Terhadap Nilai Perusahaan Otomotif yang Terdaftar di BEI. Jurnal EMB A: Jurnal Riset Ekonomi, Manajemen, Bisnis dan Akuntansi., 2(2), 879-889. https://doi.org/10.35794/emba.v2i2.4443

Pratiwi, D. N. (2017). Pengaruh Stakeholder Terhadap Carbon Emission Disclosure. Accounthink : Journal of Accounting and Finance, 2(1), 288-300. http://dx.doi.org/10.35706/acc.v2i01.732

Putra, A. A. N. D. A. \& Lestari, P. V. (2016). Pengaruh Kebijakan Dividen, Likuiditas, Profitabilitas dan Ukuran Perusahaan Terhadap Nilai Perusahaan. E-Jurnal Manajemen UNUD, 5(7), 4044 - 4070. Retrieved from https://ojs.unud.ac.id/index.php/Manajemen/article/view/20373

Rani, R. P., Hasan, A., Ilham, E. (2015). Pengaruh Karakteristik Perusahaan Terhadap Pengungkapan Tanggung Jawab Sosial Dalam Laporan Tahunan Pada Perusahaan Pertambangan yang Terdaftar di BEI Periode 2011-2013. Jurnal Fakultas Ekonomi Universitas Riau, 2(2), 1-15. Retrieved from https://jom.unri.ac.id/index.php/JOMFEKON/article/view/9028

Rompas, G. P. (2013). Likuiditas Solvabilitas dan Rentabilitas Terhadap Nilai Perusahaan Bumn yang Terdaftar di Bursa Efek Indonesia. Jurnal EMB A: Jurnal Riset Ekonomi, Manajemen, Bisnis dan Akuntansi, 1(3), 252-262. https://doi.org/10.35794/emba.v1i3.2014

Ross, S. A. (1977). The Determination of Financial Structure: The Incentive Signalling Approach. Journal of Economics, 8(1), 23-40. Retrieved from https://www2.bc.edu/thomaschemmanur/phdfincorp/MF891\%20papers/Ross\%201977.pdf

Saka, C., \& Oshika, T. (2014). Disclosure Effects, Carbon Emissions, and corporate Value. Sustainability Accounting, Management and Policy Journal, 5(1), 1-10. Retrieved from https://www.researchgate.net/publication/262901070 Disclosure effects carbon e missions and corporate value

Salvatore, D. (2005). Managerial Economics in the Global Economy. Jakarta: Salemba Empat.

Sartono, R. A. (1998). Financial Management. Yogyakarta: BPFE.

Shaw, J. C. (2003). Corporate Governance and Risk: A Systems Approach. New York: John Wiley \& Sons, Inc.

Stocker, T. (2014). The Intergovernmental Panel on Climate Change (IPCC). Climate Change 2014 Synthesis Report. University of Bern. Retrieved from https://www.ipcc.ch/site/assets/uploads/2018/05/SYR AR5 FINAL full wcover. pdf 


\section{Hapsoro \& Falih}

The Effect of Firm Size, Profitability, and Liquidity on The Firm Value Moderated ...

Thaib, I. \& Dewantoro, A. (2017). Pengaruh Profitabilitas dan Likuiditas Terhadap Nilai Perusahaan dengan Struktur Modal sebagai Variabel Intervening. Jurnal Riset Perbankan Manajemen dan Akuntansi, 1(1), 25-44. Retrieved from http://www.jrpma.spsperbanas.ac.id/index.php/jrpma/article/view/6 